\title{
Large-scale variability of planktonic net community metabolism in the Atlantic Ocean: importance of temporal changes in oligotrophic subtropical waters
}

\author{
Natalia González ${ }^{1, *}$, Ricardo Anadón $^{1}$, Emilio Marañón $^{2}$ \\ ${ }^{1}$ Universidad de Oviedo, Departamento de Biología de Organismos y Sistemas. Área de Ecología, \\ C/Catedrático Rodrigo Uría s/n, 33071 Oviedo, Spain \\ ${ }^{2}$ Universidade de Vigo, Departamento de Ecoloxía e Bioloxía Animal, 36200 Vigo, Spain
}

\begin{abstract}
We used the oxygen method (dark and light bottles) to study photic-layer-integrated microbial metabolism along a latitudinal transect in the Atlantic Ocean $\left(50^{\circ} \mathrm{S}\right.$ to $\left.50^{\circ} \mathrm{N}\right)$ during May and October 1997. The temperate region was more productive than the other oceanic environments, showing a net autotrophic balance (gross primary production/total respiration, GPP/ $R=1.41 \pm 0.34$; mean $\pm \mathrm{SE})$. The GPP/ $R$ ratio in the upwelling regions was close to $1(\mathrm{GPP} / R=1.32 \pm 0.41)$, whereas in subtropical, oligotrophic environments it tended to be lower than 1 (GPP/R $=0.83 \pm 0.27$ ). The south oligotrophic gyre showed a higher organic carbon deficit $\left(-235 \pm 167 \mathrm{mmol} \mathrm{O}_{2} \mathrm{~m}^{-2} \mathrm{~d}^{-1}\right)$ than the north oligotrophic gyre $\left(-77 \pm 162 \mathrm{mmol} \mathrm{O}_{2} \mathrm{~m}^{-2} \mathrm{~d}^{-1}\right)$. The occurrence and extent of net heterotrophic metabolism in the oligotrophic ocean (north and south subtropical gyres) are not constant and can vary as a response to seasonal variations in physical forcing. The degree of nutrient limitation is a critical factor in the control of the microbial community metabolism in the oligotrophic regions of the open ocean. Relatively weak variations in the structure of the water column in the subtropical gyres may have a major impact on the metabolic functioning of the pelagic ecosystem.
\end{abstract}

KEY WORDS: Microplankton respiration · Gross primary production $\cdot$ GPP/R balance $\cdot$ Nutrient status $\cdot$ Oligotrophy $\cdot$ Atlantic Ocean

Resale or republication not permitted without written consent of the publisher

\section{INTRODUCTION}

Knowledge of the net community production (NCP), defined as the difference between gross primary production (GPP) and total respiration $(R)$, is important for understanding the role of marine biota in the global carbon cycle. The range of the balance between heterotrophy and autotrophy spans more than 2 orders of magnitude, from gross primary production/respiration (GPP/R) ratios of ca. 0.05 to $>45$ (Duarte \& Agustí 1998). In contrast to coastal environments, the central regions of the open ocean are highly undersampled,

*E-mail: nataliag@correo.uniovi.es and therefore it is still not possible to conclude if the biota in these ecosystems acts as a net sink (e.g. Geider 1997, Williams 1998, Williams and Bowers 1999) or a source (e.g. del Giorgio et al. 1997, Kirchman 1997, Duarte \& Agustí 1998, Duarte et al. 1999) of carbon dioxide. Although the subtropical oceans are lownutrient and low-productivity regions, as a result of their large extension, they may contribute $>80 \%$ of the total marine primary production (Karl et al. 1996). For this reason, it is critical to clarify whether or not these systems are substantially in a state of organic carbon imbalance.

Several reasons may explain the current lack of agreement regarding the metabolic balance of micro- 


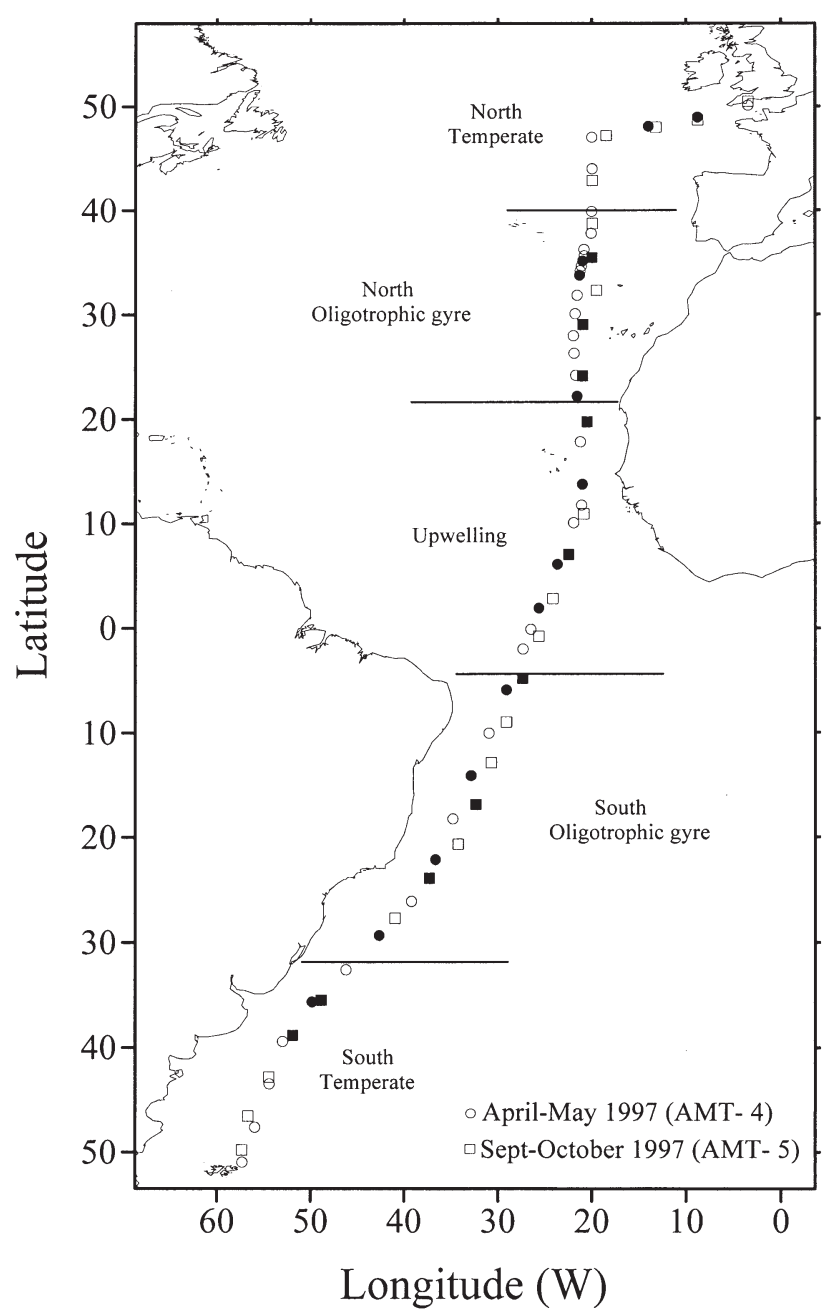

Fig. 1. CTD stations sampled during April-May 1997 and September-October 1997. Solid symbols indicate that metabolic balance measurements were taken. The latitudinal transect was divided into 5 broad regions: north temperate, north oligotrophic gyre, upwelling, south oligotrophic gyre and south temperate. See 'Results' for details

bial plankton in the open ocean. Firstly, it is possible that insufficient methodological accuracy has played a role, given that, on many occasions, the metabolic balance has been estimated from indirect comparisons of organic carbon production $\left({ }^{14} \mathrm{C}\right.$ uptake) and planktonic respiration (dark $\mathrm{O}_{2}$ consumption), leading to an overestimation of heterotrophy (Carignan et al. 2000). Secondly, the spatial distribution of currently available measurements of microplankton metabolic status is heavily biased towards coastal and high-productivity environments (see Lefèvre et al. 1994, Blight et al. 1995, Arístegui et al. 1996, Williams 1998). As a result, conclusions on the metabolic status of the open ocean have to be drawn from a relatively limited number of observations. Finally, many studies of net ecosystem production do not consider temporal variability, and the results can only be interpreted as representing static conditions of the systems under study (Duarte \& Agustí 1998, Williams 1998, Duarte et al. 1999). However, recent results clearly indicate that the oligotrophic regions of the open ocean undergo substantial temporal changes that affect the metabolic rates of different planktonic groups (Marañón et al. 2000). Prior to the present contribution, the only study that examined the extent to which temporal variability influences the net metabolic balance of the microbial communities in the oligotrophic gyres was that of González et al. (2001). Their study, however, dealt with the effects of mesoscale features on net community metabolism, and therefore had limited geographical coverage. To our knowledge, no account of the temporal variability in the metabolic balance of the open ocean has yet been provided at the basin scale.

The Atlantic Meridional Transect (AMT) programme offers the opportunity of studing large-scale latitudinal variability of plankton metabolic balance in the Atlantic Ocean from $40^{\circ} \mathrm{N}$ to $40^{\circ} \mathrm{S}$. Given that observations are carried out twice annually, it is possible to investigate also the temporal variability of remote regions such as the subtropical gyres. Within the AMT programme, we determined the large-scale latitudinal distribution of net community metabolism in the Atlantic Ocean in 2 contrasting seasons, using highprecision oxygen evolution measurements. Our main objectives were to elucidate whether the overall balance of autotrophy and heterotrophy within the central gyres varies over time and to establish whether the open ocean as a whole is substantially in a state of organic imbalance.

\section{MATERIALS AND METHODS}

Sampling was conducted during 2 cruises on board the RRS 'James Clark Ross' between Great Britain and the Falkland Islands from 22 April to 20 May 1997 (AMT-4) and 18 September to 15 October 1997 (AMT5). The location of each sampling station is indicated in Fig. 1. Sampling was carried out between 11:00 and 12:00 h local time. At each station, seawater samples for the determination of chemical and biological variables were collected with a rosette system equipped with 121 Niskin bottles. The vertical distribution of PAR (photosynthetically active irradiance) was obtained using a Sea OPS Satlantic sensor. The vertical distribution of temperature and salinity were measured with a Neil Brown Mark IIIB CTD. The density anomaly (sigma- $t$ ) was calculated from temperature and salinity following the algorithms of Fofonoff \& Millard (1983). 
Inorganic nitrate was measured on fresh samples by colorimetry using a Technicon AAII Autoanalyzer and standard techniques during AMT-4, but nano-level nitrate concentrations were measured by chemiluminescent methods during AMT-5 (Garside 1982).

Vertical profiles of chlorophyll a ( $\mathrm{chl}$ a) concentrations and ${ }^{14} \mathrm{C}$-based primary productivity were obtained following the methods detailed in Marañón et al. (2000). Concurrent measurements of ${ }^{14} \mathrm{C}$-based productivity and $\mathrm{O}_{2}$ production-consumption fluxes allowed us to assess the effect of different calculation methods (e.g. ${ }^{14} \mathrm{C}$ uptake and $\mathrm{O}_{2}$ production vs $\mathrm{O}_{2}$ production and $\mathrm{O}_{2}$ consumption) on the final estimate of metabolic balance. In order to estimate gross primary production and dark microplankton respiration rates at each station, seawater was collected from 3 discrete depths: the surface $(7 \mathrm{~m})$, the deep chlorophyll maximum (DCM), and the depth receiving $1 \%$ of surface irradiance $\left(1 \% I_{0}\right)$. Seawater samples were transferred to calibrated borosilicate glass bottles with a nominal volume of $130 \mathrm{~cm}^{3}$. For each station and depth, samples were placed on a deck incubator cooled with pumped surface seawater; 4 bottles were fixed immediately ('zero' bottles), 4 additional bottles ('dark' bottles) were covered with dense black plastic, and 4 more ('light' bottles) were covered with a set of neutral-density filters, simulating the in situ light profile. Incubations lasted for $7 \mathrm{~h}$ (until dusk). Measurements of dissolved oxygen were made by automated precision Winkler titration performed with a Methrom 716 DMS titrino, using a potentiometric end point (Pakulski et al. 1995). Microplankton respiration rate $\left(R_{\mathrm{h}},\left[\mathrm{O}_{2}\right]_{\text {zero bottle }}-\left[\mathrm{O}_{2}\right]_{\text {dark bottle }}\right)$ and net community production $\left(\mathrm{NCP}_{\mathrm{h}},\left[\mathrm{O}_{2}\right]_{\text {light bottle }}-\left[\mathrm{O}_{2}\right]_{\text {zero bottle }}\right)$ were then calculated as $\mu \mathrm{mol} \mathrm{O}_{2} \mathrm{l}^{-1} \mathrm{~h}^{-1}$. Gross primary production $\left(\mathrm{GPP}_{\mathrm{h}}\right)$ was calculated as $\mathrm{NCP}_{\mathrm{h}}+R_{\mathrm{h}}$, assuming equal dark and light microplankton respiration. We obtained a pooled variation coefficient of $0.136 \% \pm 0.008$ (mean $\pm \mathrm{SE}, \mathrm{n}=184$, range $=0.000$ to 0.75 ). Daily metabolic rates were calculated as: $R=R_{\mathrm{h}} \times 24 \mathrm{~h}_{i} \mathrm{GPP}=\mathrm{GPP}_{\mathrm{h}} \times$ hours of light; $\mathrm{NCP}=\mathrm{GPP}-R$.

All profiles in this study were depth-integrated from the surface to the bottom of the photic layer using a simple trapezoid procedure. In order to evaluate the error involved in calculating photic-layer-integrated rates using 3 depth profiles, we used the ${ }^{14} \mathrm{C}$ productivity data set from the AMT-3 cruise, during which ${ }^{14} \mathrm{C}$ experiments had been conducted at 7 depth levels on each profile (Marañón et al. 2000). Using this data set, we found no significant differences between the photic-layer-integrated estimates obtained using 3 depth levels (surface, DCM and $1 \% I_{0}$ ) and those calculated using the full, 7-depth profiles (Student's $t_{17}=$ $0.05, \mathrm{n}=18, \mathrm{p}=0.96$ ). The results of this comparison strongly suggest that our areal estimates of production and respiration, calculated from 3 depth profiles, adequately reflected the integrated $\mathrm{O}_{2}$ fluxes in the photic layer.

Regression analyses were carried out using the reduced major axis (rma) slope (McArdle 1988).

\section{RESULTS}

\section{Temporal and spatial variability in temperature, nitrate and chlorophyll $a$}

The main patterns of vertical and latitudinal distribution of temperature, nitrate concentration and chl a concentration were similar to those given by Marañón et al. (2000) for earlier cruises. The temperature distribution in the subtropical gyres showed marked temporal changes (Fig. 2). During May 1997 (AMT-4), the north subtropical gyre had a colder upper mixed layer and a deeper thermocline than in October 1997 (AMT-5). The south subtropical gyre showed the opposite pattern, with colder upper mixed waters and a deeper thermocline in October 1997. The upward displacement of isotherms during both cruises between 0 and $20^{\circ} \mathrm{N}$ reflected the effects of the African and equatorial upwellings (Fig. 2). A well-mixed water column was found in the south temperate waters, with temperature decreasing progressively southwards from 16 to $12^{\circ} \mathrm{C}$ during both cruises. During most of the transect, surface waters showed undetectable levels of nitrate

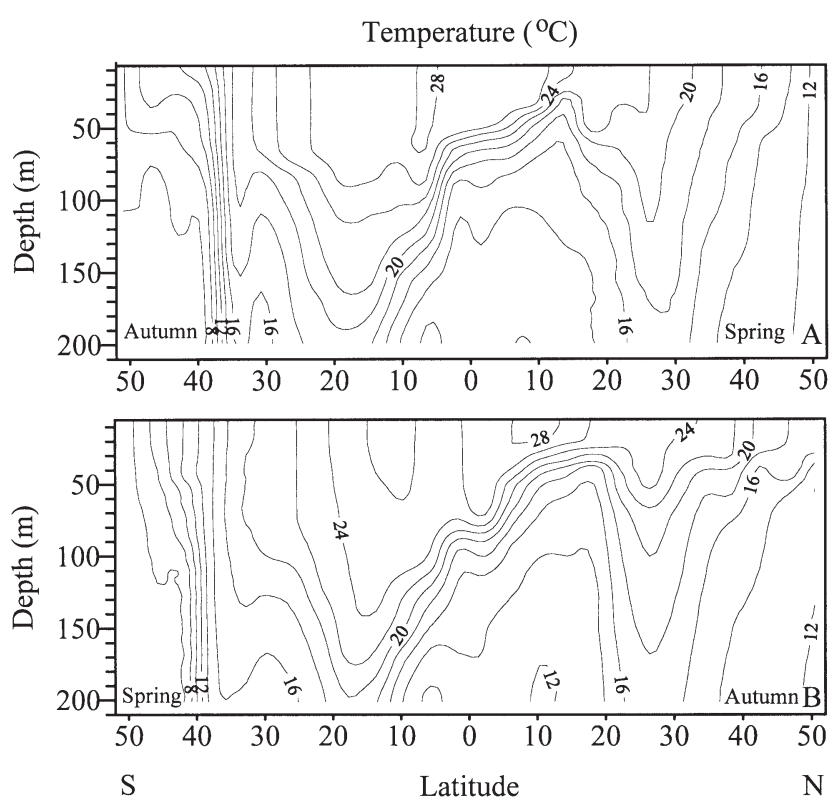

Fig. 2. Latitudinal and vertical distribution of temperature during (A) April and May 1997 (AMT-4) and (B) September and October 1997 (AMT-5) 
$(<0.1 \mu \mathrm{M})$, but the effect of the equatorial and African upwellings were also reflected in the nitrate distribution (Fig. 3), with subsurface concentrations $>0.5 \mu \mathrm{M}$ between 0 and $20^{\circ} \mathrm{N}$.

The equatorial region showed temporal changes in the nitracline depth, which was deeper during May
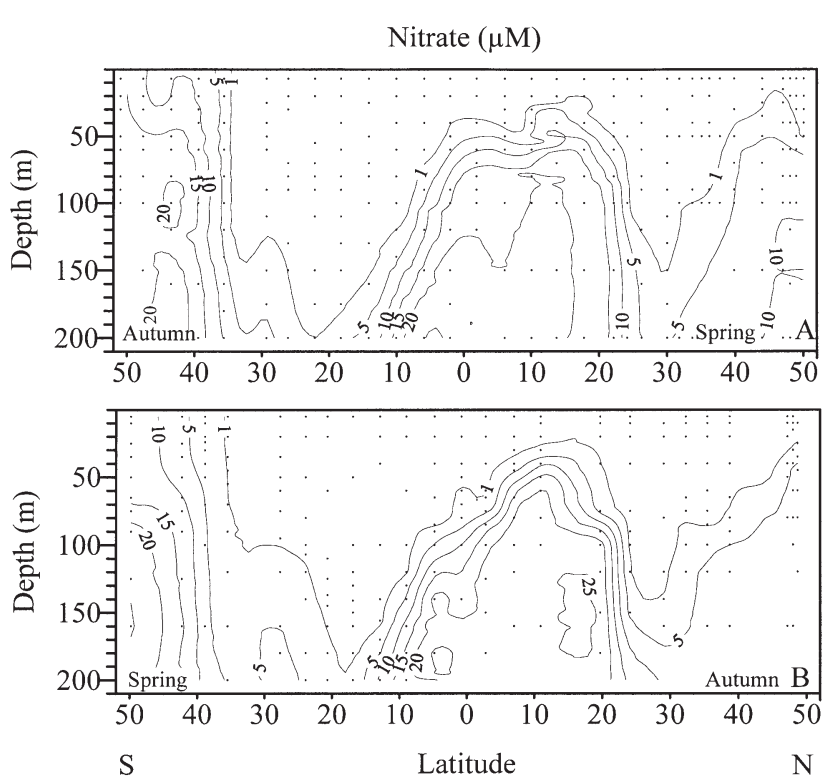

Fig. 3. Latitudinal and vertical distribution of nitrate concentration during (A) April and May 1997 (AMT-4) and (B) September and October 1997 (AMT-5)
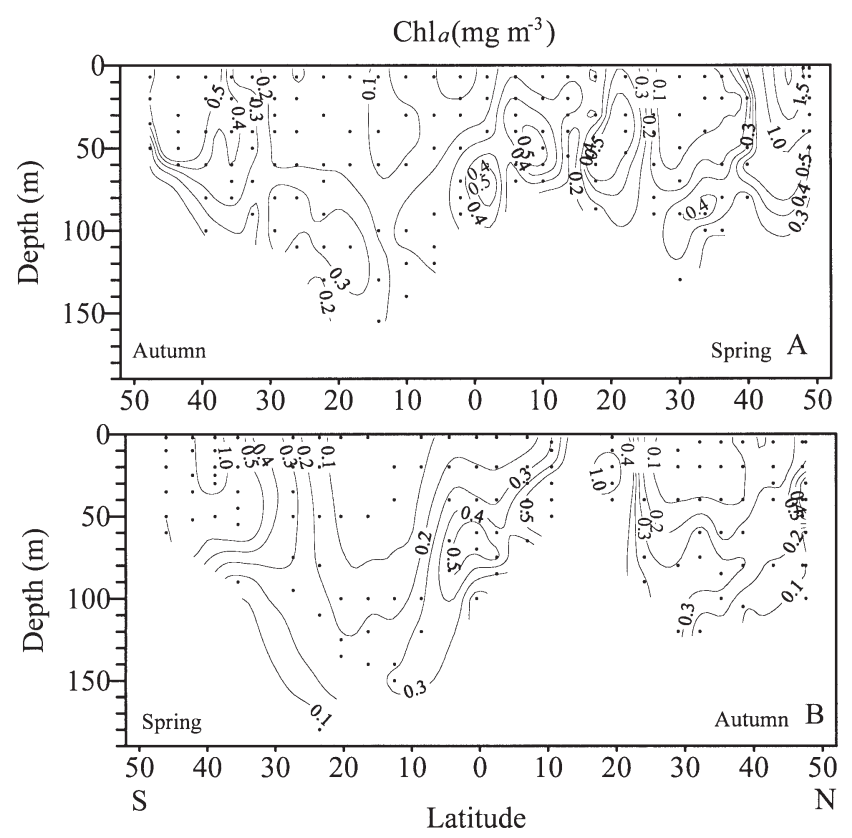

Fig. 4. Latitudinal distribution of chlorophyll a during (A) April and May 1997 (AMT-4) and (B) September and October 1997 (AMT-5)
1997 than October 1997. The vertical distribution of nitrate in south temperate waters was relatively homogeneous, with concentrations above $1 \mu \mathrm{M}$ during both cruises. Temporal changes in the nitracline depth were also found in the subtropical gyres. In the north subtropical gyre, the vertical extent of the nitrate-depleted waters in May 1997 was deeper than in October 1997. whereas the opposite pattern was observed in the south subtropical gyre.

Lowest chl a concentrations were measured in the subtropical gyres, where the upper mixed layer was nitrate-depleted, with values lower than $0.2 \mathrm{mg} \mathrm{m}^{-3}$ along most of the transect during both cruises (Fig. 4). In contrast, the highest chl a concentrations were measured in the temperate and African upwelling regions. The equatorial region showed a clear deep chl a maximum around $80 \mathrm{~m}$, with values up to $0.5 \mathrm{mg} \mathrm{m}^{-3}$ during both cruises (Fig. 4).

\section{Temporal and latitudinal variability in community metabolism}

The spatial and temporal distributions of depth-integrated $R$ and GPP within the euphotic layer were characterized by rates lower than $200 \mathrm{mmol} \mathrm{O} \mathrm{m}^{-2} \mathrm{~d}^{-1}$ along most of the transect during both cruises (Fig. 5). The metabolic rates during October 1997 were lower and less variable than those measured during May 1997. In general, high GPP rates occurred outside the
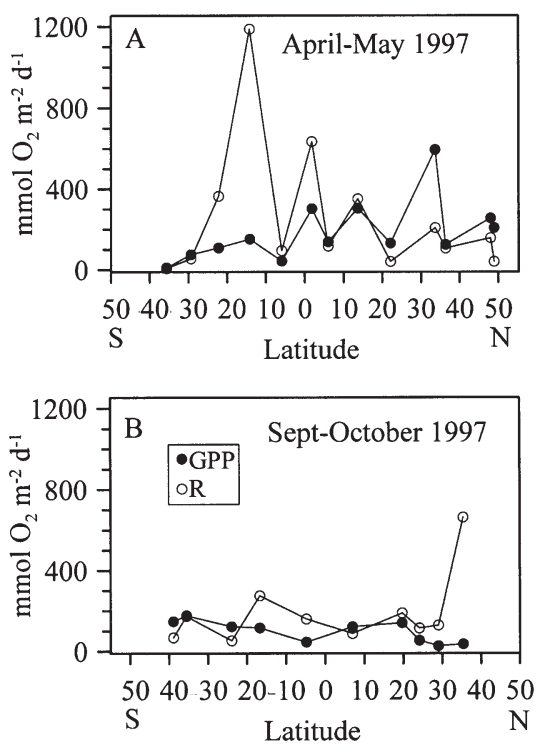

Fig. 5. Latitudinal distribution of depth-integrated rates of microplankton respiration $(R)$ and gross primary production (GPP) during (A) April and May 1997 (AMT-4) and (B) September and October 1997 (AMT-5) 


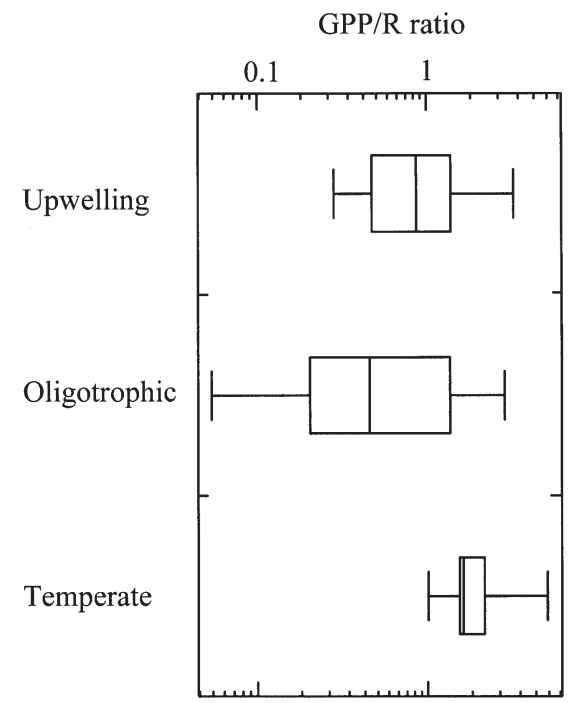

Fig. 6. Gross primary production (GPP) to microplankton respiration $(R)$ ratio in different regions (temperate, oligotrophic and upwelling) along the latitudinal transect during April and May 1997 (AMT-4) and September and October 1997 (AMT-5). Boxes enclose 25 and $75 \%$ percentiles of the data, central line represents median, and the bars encompass $95 \%$ of the data

subtropical regions, except for a local maximum in the North subtropical gyre during May 1997 (>500 mmol $\mathrm{O}_{2} \mathrm{~m}^{-2} \mathrm{~d}^{-1}$ ). The highest $R$ rates were measured in the south subtropical gyre during May 1997 and in the north subtropical gyre during October 1997 (Fig. 5).

In order to summarise the main patterns of geographical variation in community metabolism, we divided the meridional transect into 3 broad regions: temperate $\left(>40^{\circ} \mathrm{N}\right.$ and $\left.>32^{\circ} \mathrm{S}\right)$, subtropical oligotrophic gyres (from 22 to $40^{\circ} \mathrm{N}$ and from 5 to $32^{\circ} \mathrm{S}$ ) and upwelling (from $5^{\circ} \mathrm{S}$ to $20-22^{\circ} \mathrm{N}$ ), which included both the Equatorial and the Mauritanian upwelling zones. The ratio between depth-integrated GPP and $R$ showed marked differences between regions (Fig. 6). The temperate region was more productive than the other oceanic environments: $100 \%$ of stations displayed autotrophic balance $(\mathrm{GPP} / R=1.41 \pm 0.34$; mean $\pm \mathrm{SE}$ ), producing more organic carbon than they consumed. The tendency in the equatorial and the Mauritanian upwelling regions was for GPP and $R$ rates to be similar, leading the GPP/ $R$ ratio close to $1(\mathrm{GPP} / R=$ $1.32 \pm 0.41)$. In the oligotrophic subtropical communities, the GPP $/ R$ balance tended to be $<1$ (GPP $/ R=$ $0.83 \pm 0.27$ ). Fig. 7 shows the relationship between GPP and $R$ in oligotrophic and eutrophic regions. The GPP- $R$ relationship was significant outside the oligotrophic domain (upwelling and temperate) using both volumetric (Fig. 7A: $\mathrm{r}^{2}=0.38, \mathrm{p}<0.0005, \mathrm{n}=28$ ) and areal (Fig. 7B: $\mathrm{r}^{2}=0.45, \mathrm{p}<0.05, \mathrm{n}=11$ ) rates, but not in the oligotrophic region.

\section{Oligotrophic domains}

In order to evaluate the importance of temporal variability in the north and south oligotrophic gyres, we calculated average values for several selected physical, chemical and biological variables during May 1997 and October 1997 (Table 1). Differences in daily incident irradiance (PAR) were significant between cruises and hemispheres $\left(F_{1,20}=17, \mathrm{p}<0.001, \mathrm{n}=24\right)$. The mixing depth was distinguishable by temperatures differing by $>0.25^{\circ} \mathrm{C}$ from those at the surface (Johnson \& Howd 2000). Compared to the north oligotrophic gyre, the south oligotrophic gyre had a deeper upper mixed layer $\left(F_{1,22}=39, \mathrm{p}<0.0001, \mathrm{n}=25\right)$, warmer surface waters $\left(F_{1,22}=22, \mathrm{p}<0.0005, \mathrm{n}=25\right)$, deeper nitratedepletion waters $\left(F_{1,22}=15, \mathrm{p}<0.001, \mathrm{n}=25\right)$, and lower integrated nitrate concentration $\left(F_{1,22}=5, \mathrm{p}<\right.$ 0.05, $\mathrm{n}=25$; Table 1).

In summary, the South oligotrophic gyre tended to show a more stratified water column structure, with a warmer upper mixed layer and deeper and more
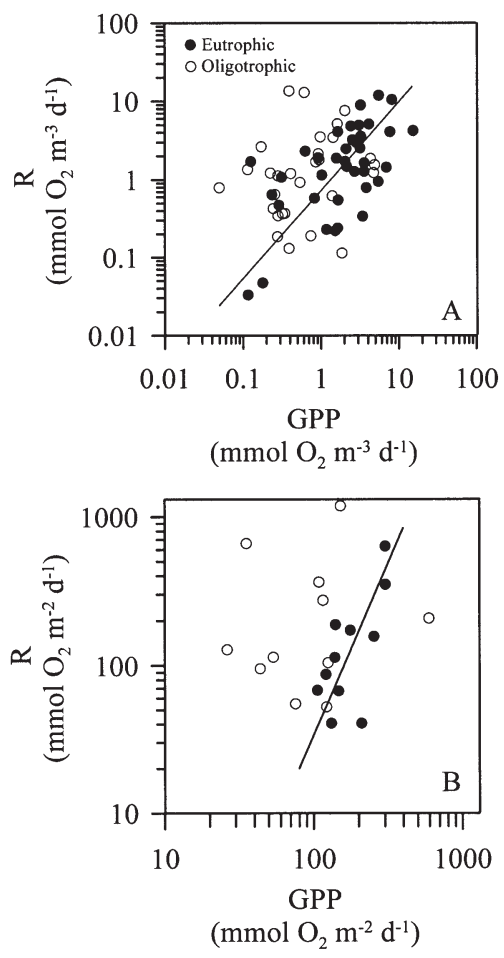

Fig. 7. Relationship between gross primary production (GPP) and respiration $(R)$ in oligotrophic and eutrophic regions using (A) volumetric and (B) areal rates, during April and May 1997 and September and October 1997. Continuous lines indicate the reduced major axis linear regression calculated for eutrophic regions. The parameters of the linear regression model are: (A) $X(\mathrm{GPP}), Y(R), a(1.13 \pm 0.07), b(-0.13 \pm 0.16)$, $\mathrm{r}^{2}=0.38, \mathrm{n}=28, \mathrm{p}<0.0005$; (B) $X(\mathrm{GPP}), Y(R), a(2.32 \pm 0.31)$, $b(-3.11 \pm 2.92), \mathrm{r}^{2}=0.45, \mathrm{n}=11, \mathrm{p}<0.05$ 
Table 1. Average values ( \pm SE) of selected physical, chemical and biological variables in the oligotrophic regions during April and May 1997 and September and October 1997. Variables shown are depth of the upper mixed layer $\left(Z_{\text {uml, }}\right.$ m), surface temperature $\left(T,{ }^{\circ} \mathrm{C}\right)$, nitracline depth $\left(Z_{\mathrm{N}}, \mathrm{m}\right)$, nitrate concentration integrated over the first $120 \mathrm{~m}$ (Nitrate, mmol $\left.\mathrm{NO}_{3} \mathrm{~m}^{-2}\right)$, daily average incident irradiance (PAR, $\mu \mathrm{mol} \mathrm{m} \mathrm{m}^{-2} \mathrm{~s}^{-1}$ ) and integrated chlorophyll a concentration $\left(\mathrm{mg} \mathrm{m}^{-2}\right)$ within the photic layer. Also indicated are the latitudinal limits of each region

\begin{tabular}{|c|c|c|c|c|c|c|c|}
\hline Period & Region & $Z_{\text {uml }}$ & $T$ & $Z_{\mathrm{N}}$ & Nitrate & PAR & Chl a \\
\hline Apr + May & $10^{\circ} \mathrm{S}-35^{\circ} \mathrm{S}$ & $74 \pm 4$ & $25 \pm 1$ & $137 \pm 9$ & $2 \pm 2$ & $374 \pm 43$ & $23 \pm 2$ \\
\hline Sep + Oct & $10^{\circ} \mathrm{S}-35^{\circ} \mathrm{S}$ & $74 \pm 12$ & $23 \pm 1$ & $104 \pm 18$ & $24 \pm 13$ & $863 \pm 70$ & $28 \pm 2$ \\
\hline Apr + May & $22^{\circ} \mathrm{N}-40^{\circ} \mathrm{N}$ & $35 \pm 3$ & $18 \pm 1$ & $63 \pm 12$ & $103 \pm 48$ & $981 \pm 53$ & $38 \pm 10$ \\
\hline Sep + Oct & $22^{\circ} \mathrm{N}-40^{\circ} \mathrm{N}$ & $27 \pm 1$ & $20 \pm 1$ & $60 \pm 16$ & $66 \pm 27$ & $926 \pm 63$ & $20 \pm 2$ \\
\hline
\end{tabular}

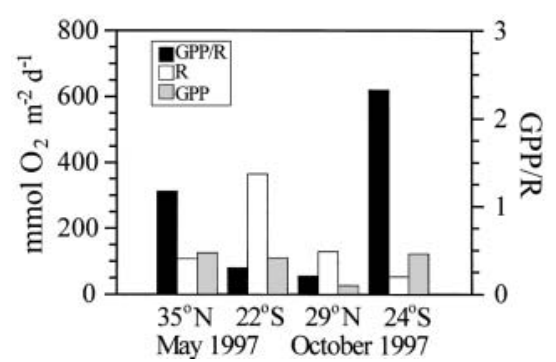

Fig. 8. Depth-integrated gross primary production (GPP), microplankton respiration $(R)$ and GPP/ $R$ ratio of selected stations in the north and south subtropical gyres during May 1997 (AMT-4) and October 1997 (AMT-5)

marked pycnocline and nitracline. These differences should not be considered representative of the entire subtropical gyres, as they reflect the particular location of the cruise track in each hemisphere (see Fig. 1). Concerning temporal variability in the subtropical gyres, we observed a tendency for colder waters and higher nitrate concentration during spring periods (northern part of the transect during May 1997 and southern part of the transect during October 1997). Depth-integrated chl $a$ in the north gyre was higher during May 1997 than during October 1997, whereas the opposite was true for the south gyre (Table 1). The temporal variability in community metabolism in the oligotrophic regions of the open ocean remains poorly resolved. In our study, we observed opposite temporal (from May 1997 to October 1997) changes in the metabolic balance of each oligotrophic gyre (Fig. 8).

GPP tended to be higher during spring, whereas $R$ tended to be lower, resulting in autotrophic balances $(\mathrm{GPP} / R>1)$ during spring and heterotrophic balances $(\mathrm{GPP} / R<1)$ during autumn $\left(F_{1,9}=7.61, \mathrm{p}<0.05, \mathrm{n}=\right.$ $11)$. The general picture that emerges from our observations is that a significant degree of temporal variability exists in the oligotrophic gyres: net autotrophy dominates during periods of higher vertical mixing whereas net heterotrophy prevails during periods of enhanced stratification. It has recently been shown that the latitudinal variability in phytoplankton photosynthetic parameters is negatively correlated with the depth of the nitracline, suggesting that the rate of nutrient supply is of paramount importance in the control of primary production over large spatial scales in the Atlantic Ocean (Marañón \& Holligan 1999). Given that most of the variability in the metabolic balance of open-ocean environments is due to changes in production rather than respiration (del Giorgio et al. 1997, Duarte \& Agustí 1998, Williams 1998), it seemed appropriate to explore if there is a link between nutrient supply status and the net metabolism of the microbial communities in the oligotrophic gyres. In order to obtain an index of nutrient availability at each station, we followed the approach proposed by Behrenfeld et al. (2001), which is based on the relationship between the depth of the nitracline $\left(Z_{N}\right)$ and the depth of the pycnocline $\left(Z_{M}\right)$ as a function of the mixing-stratification history of the water column. $Z_{\mathrm{N}}$ was identified as the depth of the first sample, in which $\mathrm{NO}_{3}{ }^{-}$concentration was above the detection levels (>0.05 $\mu \mathrm{M})$, whereas $Z_{\mathrm{M}}$ described temperature changes differing by $>0.25^{\circ} \mathrm{C}$ from those at the surface (Johnson \& Howd 2002). A high correspondence between the location of $Z_{\mathrm{N}}$ and $Z_{\mathrm{M}}$ (Fig. 9A,B) is taken to represent a situation of relatively low nutrient stress (as would be expected shortly after a mixing event), whereas a $Z_{\mathrm{N}}$ significantly deeper than $Z_{\mathrm{M}}$ (Fig. 9C, D) implies that stratification has persisted long enough to cause high nutrient stress of the phytoplankton in the upper layer.

According to the above criteria, the measurements of metabolic balance were grouped into 'high nutrient stress' and 'low nutrient stress' stations (Fig. 10). Low nutrient stress led the microbial metabolism to net autotrophy (GPP/R $>1)$, whereas $R$ tended to exceed GPP under high nutrient stress (Fig. 10). These differences in community metabolism between high and low nutrient stress situations were significant for the overall transect and particularly within the oligotrophic domains $\left(F_{1,21}=8.04, \mathrm{p}<0.01, \mathrm{n}=23\right.$ and $F_{1,9}=21, \mathrm{p}<$ 
$0.005, \mathrm{n}=11$, respectively). Our results indicate that in the oligotrophic regions a direct linkage exists between the degree of nutrient limitation and the net metabolism of the microbial community.

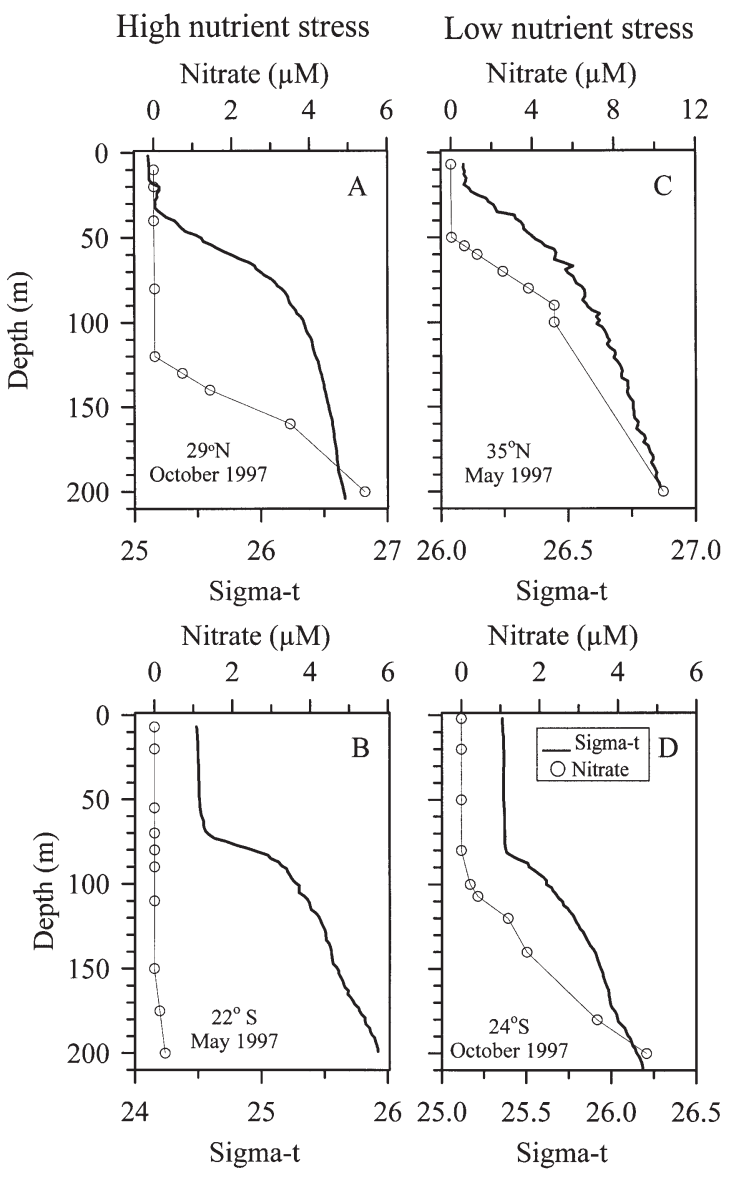

Fig. 9. Representative profiles of density (continuous line) and nitrate concentration for $(\mathrm{A}, \mathrm{B})$ high and $(\mathrm{C}, \mathrm{D})$ low nutrientstress conditions in oligotrophic regions of the Atlantic Ocean during April and May 1997 (AMT-4) and September and October 1997 (AMT-5)

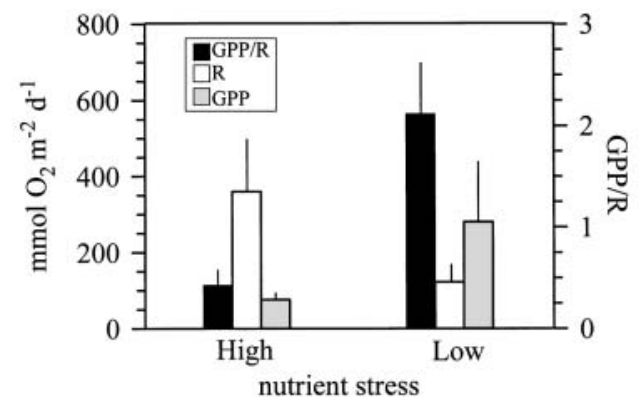

Fig. 10. Average values for depth-integrated gross primary production (GPP), microplankton respiration $(R)$ and GPP/R ratio in oligotrophic stations under high and low nutrientstress conditions in April and May 1997 and September and October 1997. Error bars indicate standard errors of the mean. See 'Results' for details

\section{DISCUSSION}

\section{Methodological considerations}

Some authors (e.g. del Giorgio et al. 1997, Duarte et al. 1999, 2001) consider the heterotrophy of oligotrophic areas to be the rule rather than the exception, and regard allochthonous inputs as essential for the functioning of these regions (e.g. Smith \& MacKenzie 1987, Bauer \& Druffel 1998, Duarte et al. 1999, 2001). However, other authors (Geider 1997, Williams 1998) question how the heterotrophy in remote environments such as the central oligotrophic gyres can be sustained by organic matter imports. Based on longterm observations and measurements, it has been demonstrated that $\mathrm{O}_{2}$ production estimates are significantly greater than estimates derived from ${ }^{14} \mathrm{C}$ uptake (Shulenberger \& Reid 1981). Thus, Carignan et al. (2000) considered that the reported regional imbalance in the open oceans is a consequence of methodological uncertainties such as $P / R$ estimations based on different methods $\left({ }^{14} \mathrm{C}\right.$ incorporation and $\mathrm{O}_{2}$ consumption). Our metabolic estimations ( $P / R$ balance) were calculated as $\mathrm{O}_{2}$ production and consumption, and were compared with $P / R$ ratios estimated using ${ }^{14} \mathrm{C}$ based values of gross photosynthesis. Experiments on ${ }^{14} \mathrm{C}$ uptake and $\mathrm{O}_{2}$ production were simultaneous, and the photosynthetic quotient (PQ) used to convert oxygen to carbon units was 1 . The fact that we measured ${ }^{14} \mathrm{C}$ uptake and $\mathrm{O}_{2}$ production rates concurrently allowed us to evaluate the extent to which the determination of net community metabolism is sensitive to the method of calculation used. When the metabolic balance was computed from $\mathrm{O}_{2}$ exchange rates only, $<50 \%$ of the communities were net heterotrophic (60\% within the oligotrophic domain). However, when the $P / R$ balance was calculated from the combined ${ }^{14} \mathrm{C}$ uptake and $\mathrm{O}_{2}$ consumption rates, $>80 \%$ of the communities displayed a net heterotrophic balance (100\% within the oligotrophic domain). GPP, net primary production (GPP minus auto-trophic respiration) and NCP are very different metabolic properties (Williams 1993). Thus, photosynthesis measured with ${ }^{14} \mathrm{C}$ can be an intermediate value between GPP and net production (Steemann Nielsen 1952), depending on the duration of the incubation. When ${ }^{14} \mathrm{C}$ fixation approximates GPP, there will be a high correlation between GPP and ${ }^{14} \mathrm{C}$ incorporation data. However, in our study this relationship was weak $(\mathrm{r}=0.43, \mathrm{p}<0.001, \mathrm{n}=59$, data not shown), and therefore ${ }^{14} \mathrm{C}$ uptake may not be comparable with GPP. In agreement with Carignan et al. (2000), our results show that the $P / R$ ratios based on indirect comparisons of organic carbon production $\left({ }^{14} \mathrm{C}\right.$ uptake) and planktonic respiration (dark $\mathrm{O}_{2}$ consumption) will tend to overestimate the degree of heterotro- 
phy and might mask the spatio-temporal changes observed in microbial metabolism in the oligotrophic gyres. However, our observations do indicate that heterotrophy is not a methodological artefact but a frequent condition in the oligotrophic ocean. As we shall discuss below, the occurrence and extent of net heterotrophic metabolism in the oligotrophic ocean are not constant and can vary as a response to seasonal variations in physical forcing.

\section{Metabolic balance of the open ocean}

As defined in the present study, temperate regions comprise the North Atlantic current drift (NADR) and the South Subtropical Convergence (SSTC), both areas of active hydrodynamism (White \& Heywood 1995, Froneman et al. 1999). These temperate regions were sampled during spring and autumn, when the water column is relatively cold and well mixed, nutrients are detectable throughout the water column, and the annual maximum chlorophyll content is usually observed (Campbell \& Aarup 1992). These productive, cold-water environments generally showed net autotrophy, whereby the planktonic communities produce more organic carbon than they consume, thereby acting as a net sink of $\mathrm{CO}_{2}$. Other authors have found similar results at higher latitudes, in both the South and North Atlantic Ocean (see review in Williams 1998). The occurrence of an organic carbon surplus in these net autotrophic environments agrees with the dominant role of mid- and high-latitude regions in global sinking fluxes of biogenic carbon (Buesseler 1998). Efforts have been made to understand the processes that control seasonal variability in the Southern Ocean, considered a region of great uncertainty from the point of view of its possible role as a source or a sink of atmospheric $\mathrm{CO}_{2}$ (Attwood \& Monteiro 1994). However, nothing is known about the seasonal trends in the metabolic balance of the South Atlantic oligotrophic gyre. This lack of metabolic measurements makes our observations relevant for a better understanding of the global ocean, since the South Atlantic oligotrophic gyre covers almost $25 \%$ of the Atlantic Ocean surface (Longhurst et al. 1995). Our results confirm that the planktonic communities of the oligotrophic regions, in which picoplankton accounts for a high percentage of the total phytoplankton abundance and production (Marañón et al. 2001), tend to be net heterotrophic and therefore must be sustained partially by inputs of allochthonous organic carbon. By making a series of assumptions on the surface area of the south and north oligotrophic gyres (Longhurst et al. 1995) and taking into account the average metabolic balance within the gyres in spring and autumn, it is possible to obtain a gross picture of the overall metabolic balance of the oligotrophic Atlantic Ocean. The organic carbon deficit within the south subtropical gyre would fall between 5.3 and $31.3{\mathrm{Gt} \mathrm{C} \mathrm{yr}^{-1}}^{-1}$ (Table 2), whereas in the north subtropical gyre the net

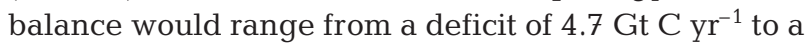
surplus of 1.6 Gt C $\mathrm{yr}^{-1}$ (Table 2).

Recent studies have attempted to identify possible sources of organic matter that could sustain the heterotrophy in these remote oligotrophic systems (e.g. Duarte et al. 2001, González et al. 2001). Continental shelves are considered important sources of dissolved organic matter (DOC) that could fuel respiration in the open oceans (Bauer \& Druffel 1998). However, Williams \& Bowers (1999) pointed out that inputs of DOC from upwelling regions or from net autotrophic areas would also be associated with concurrent inputs of nutrients and subsequent eutrophication, thereby enhancing autotrophy. It is well known that DOC represents a significant reservoir of reduced carbon in the ocean (Kirchman et al. 1991, Carlson \& Ducklow 1996). Although a large portion of the bulk DOC in the surface ocean is recalcitrant, there is evidence that it can be used by pelagic microbes (e.g. Tranvik 1992, Amon \& Benner 1994), which could help to explain the carbon deficit in the oligotrophic areas.

Table 2. Compilation of average ( \pm SE), and minimum and maximum net community production (NCP) in several oligotrophic provinces of the North and South Atlantic (NASE and SATL, respectively). Also indicated are the annual carbon deficits for each province. CNRY: Eastern (Canary) coastal province

\begin{tabular}{|c|c|c|c|}
\hline Source & Area $\left(10^{6} \mathrm{~km}^{2}\right)$ & $\begin{array}{c}\mathrm{NCP} \\
\left(\mathrm{mmol} \mathrm{O}_{2} \mathrm{~m}^{-2} \mathrm{~d}^{-1}\right)\end{array}$ & $\begin{array}{l}\text { Deficit } \\
\left(\mathrm{Gt} \mathrm{C} \mathrm{yr}^{-1}\right)\end{array}$ \\
\hline This study & 4.45 (NASE) & $-77 \pm 162(-239,+185)$ & $(-4.7,+1.65)$ \\
\hline González et al. (2001) & 4.2 (NASE) & $-103 \pm 40(-63,+143)$ & $(-2.6,-1.15)$ \\
\hline Duarte et al. (2001) & $5.26(\mathrm{NASE}+\mathrm{CNRY})^{\mathrm{a}}$ & -38 & -0.5 \\
\hline This study & 17.77 (SATL) & $-235 \pm 167(-402,-68)$ & $(-31.3,-5.3)$ \\
\hline \multicolumn{4}{|l|}{ a Longhurst et al. (1995) } \\
\hline
\end{tabular}




\section{Importance of temporal variability}

Seasonal variability is considered to be latitude-dependent, with the lowest variations at low and mid latitudes (e.g. Longhurst 1998), where the water column tends to be strongly stratified throughout most of the year. These low-latitude systems have been considered to be stable and homogenous, with random stochastic events explaining the variability observed in biological parameters (e.g. DiTullio \& Laws 1991). However, recent reports have provided clear evidence of a large degree of temporal variability within the oligotrophic regions in DOC stocks (Carlson et al. 1994), new production (Campbell \& Aarup 1992), chl a concentration (Letelier et al. 1993), hetero- and autotrophic biomass (Buck et al. 1996, Campbell et al. 1997), and phytoplankton productivity and growth rates (Marañón et al. 2000). González et al. (2001) observed significant temporal changes in the planktonic community metabolism of the NE subtropical Atlantic.

In the subtropical gyres, the strong vertical stratification of the water column limits the supply of nutrients from below the thermocline to the euphotic layer, which leads to low rates of primary production. However, several physical mechanisms exist that can be sources of temporal variability in the structure of the water column and the location of the nitracline. Among these are storms (Eppley \& Renger 1988), wind-forced currents (Lee et al. 1994), internal waves (Uz et al. 2001) and mesocale eddies (e.g. McGillicuddy et al. 1998, Oschlies \& Garçon 1998). These episodic events cause mixing of water masses and enhance the supply of nutrients to the upper layer, indicated by an increased correspondence between the location of the nitracline and the location of the pycnocline (see 'Results'). As discussed below, these upper-layer dynamics are likely to significantly affect the metabolic balance of the microbial community.

According to some authors (Duarte et al. 1999, 2001, González et al. 2001), the GPP/ $R$ ratio of the communities tend to increase as GPP increase, suggesting that the planktonic GPP/ $R$ ratio is mainly determined by factors directly controlling primary production, such as nutrients (del Giorgio \& Peters 1994). Therefore, the presence of nutrients within the upper mixed layer should increase primary production more than respiration, pushing the community metabolism towards autotrophy. Our results suggest that the degree of nutrient limitation (as reflected in the relative locations of $Z_{\mathrm{N}}$ and $Z_{\mathrm{M}}$ ) is a critical factor in the control of the microbial community metabolism in the oligotrophic ocean. In contrast with the traditional view of the subtropical gyres as steady-state systems, our results confirm that relatively weak temporal variations in the structure of the water column may have a major impact on the functioning of the pelagic ecosystem. Low sampling frequency and the scarcity of time-series data make it difficult to resolve the natural variability of the net oxygen fluxes in the oligotrophic gyres (Karl 1999). Our results highlight the critical importance of taking into account temporal variability if we are to solve the puzzle of the metabolic status of the open ocean.

Acknowledgements. We thank principal scientists Tony Bale and Jim Aiken for their help during the work at sea, as well as the captain and crew of the RRS 'James Clark Ross' for excellent support. Thanks are also given to Malcolm Woodward (Plymouth Marine Laboratory, PML) for providing nutrient data and Nigel Rees (PML) for assisting us in the use of the AMT database. Comments from 3 reviewers greatly improved the earlier version of the manuscript. This work was supported by CANIGO Grant CE-96-MAS3-CT-0060 and CICYT ACCION ESPECIAL (CC95 MAR $1970 \mathrm{E}$ ) and is part of a doctoral thesis from the University of Oviedo.

\section{LITERATURE CITED}

Amon RMW, Benner R (1994) Rapid cycling of high-molecularweight dissolved organic matter in the ocean. Nature 369: $549-552$

Arístegui JM, Montero F, Ballesteros S, Basterretxea G, Lenning K (1996) Planktonic primary production and microbial respiration measured by ${ }^{14} \mathrm{C}$ assimilation and dissolved oxygen changes in coastal waters of the Antarctic Peninsula during austral summer: implications for carbon flux studies. Mar Ecol Prog Ser 132:191-201

Attwood CG, Monteiro PMS (1994) Advances in the global $\mathrm{CO}_{2}$ budget. S Afr J Sci 90:315-316

Bauer JE, Druffel ERM (1998) Ocean margins as a significant source of organic matter to the deep open ocean. Nature 392:482-485

Behrenfeld MJ, Marañón E, Siegel DA, Hooker SB (2002) Photoacclimation and nutrient based model of lightsaturated photosynthesis for quantifying oceanic primary production. Mar Ecol Prog Ser 228:103-117

Blight SP, Bentley TL, Lefevre D, Robinson C, Rodrigues R, Rowland J, Williams PJB (1995) Phasing of autotrophic and heterotrophic plankton metabolism in a temperate coastal ecosystem. Mar Ecol Prog Ser 128:61-75

Buck KR, Chavez FP, Campbell L (1996) Basin-wide distributions of living carbon components and the inverted trophic pyramid of the central gyre of the North Atlantic Ocean, summer 1993 Aquat Microb Ecol 10:283-298

Buesseler KO (1998) The decoupling of production and particulate export in the surface ocean. Global Biogeochem Cycles 12:297-310

Campbell JW, Aarup T (1992) New production in the North Atlantic derived from seasonal patterns of surface chlorophyll. Deep-Sea Res 39:1669-1694

Campbell L, Liu H, Nolla HA, Vaulot D (1997) Annual variability of phytoplankton and bacteria in the subtropical North Pacific Ocean at Station ALOHA during the 1991-1994 ENSO event. Deep-Sea Res Part I 44:167-192

Carignan R, Planas D, Vis C (2000) Planktonic production and respiration in oligotrophic Shield lakes. Limnol Oceanogr 45:189-199

Carlson CA, Ducklow HW (1996) Growth of bacterioplankton and consumption of dissolved organic carbon in the Sargasso Sea. Aquat Microb Ecol 10:69-85

Carlson CA, Ducklow HW, Michaels AF (1994) Annual flux of 
dissolved organic carbon from the euphotic zone in the northwestern Sargasso Sea. Nature 371:405-408

del Giorgio PA, Peters RM (1994) Patterns in planktonic P:R ratios in lakes: Influence of cake trophey and dissolved organic carbon. Limnol Oceanogr. 39:772-787

del Giorgio PA, Cole JJ, Cimbleris A (1997) Respiration rates in bacteria exceed phytoplankton production in unproductive aquatic systems. Nature 385:148-151

DiTullio GR, Laws EA (1991) Impact of an atmosphericoceanic disturbance on phytoplankton community dynamics in the North Pacific Central Gyre. Deep Sea Res Part I 38:1305-1329

Duarte CD, Agustí S (1998) The $\mathrm{CO}_{2}$ balance of unproductive aquatic ecosystems. Science 281:234-236

Duarte CD, Agustí S, del Giorgio PA, Cole JJ (1999) Regional carbon imbalances in the oceans. Science 284:1735b

Duarte CD, Agustí S, Arístegui J, González N, Anadón R (2001) Evidence for a heterotrophic subtropical northeast Atlantic. Limnol Oceanogr 46:425-428

Eppley RW, Petersen BJ (1979) Particulate organic matter flux and planktonic new production in the deep ocean. Nature 282:677-680

Eppley RW, Renger EH (1988) Nanomolar increase in surface layer nitrate concentration following a small wind event. Deep-Sea Res Part I 35:1119-1125

Fofonoff NP, Millard RC Jr (1983) Algorithms for computation of fundamental properties of seawater. UNESCO Tech Pap Mar Sci 44:53

Froneman PW, McQuaid CD, Laubscher RK (1999) Size-fractionated primary production studies in the vicinity of the Subtropical Front and an adjacent warm-core eddy south of Africa in austral winter. J Plankton Res 21:2019-2035

Garside C (1982) Chemiluminescent technique for the determination of nanomolar concentrations of nitrate and nitrite in seawater. Mar Chem 11:159-167

Geider RJ (1997) Photosynthesis or planktonic respiration? Nature 388:132-133

González N, Anadón R, Mouriño B, Fernández E, Sinha B, Escánez J, de Armas D (2001) The metabolic balance of the planktonic community in the North Atlantic Subtropical Gyre: the role of mesoscale instabilities. Limnol Oceanogr 46:946-952

Johnson Z, Howd P (2000) Marine photosynthetic performance forcing and periodicity of the Bermuda Atlantic times series, 1989-1995. Deep-Sea Res Part I 47:1485-1512

Kirchman DL (1997) Microbial breathing lessons. Nature 385 : 121-122

Karl DM (1999) A sea of change: biogeochemical variability in the North Pacific Subtropical Gyre. Ecosystems 2:181-214

Karl DM, Christian JR, Dore JE, Hebel DV, Letelier RM, Tupas LM, Winn CW (1996) Seasonal and interannual variability in primary production and particulate flux at Station ALOHA. Deep-Sea Res Part II 43:539-568

Kirchman DL, Suzuki Y, Garside C, Ducklow HW (1991) High turnover rates of dissolved organic carbon during a spring phytoplankton bloom. Nature 352:612-614

Lee DK, Niiler P, Warn-Varnas A, Piacsek S (1994) Wind-driven secondary circulation in ocean mesoscale. J Mar Res 52:371-396

Lefèvre D, Bentley TL, Robinson C, Blight SP, Williams PJB (1994) The temperature response of gross and net commu-

Editorial responsibility: Otto Kinne (Editor), Oldendorf/Luhe, Germany nity production and respiration in time-varying assemblages of temperate marine micro-plankton. J Exp Mar Biol Ecol 184:201-215

Letelier RM, Bidigare RR, Hebel DV, Ondrusek M, Winn CD, Karl DM (1993) Temporal variability of phytoplankton community structure based on pigment analysis. Limnol Oceanogr 38:1420-1437

Longhurst A, Sathyendranath S, Platt T, Caverhill C (1995) An estimate of global primary production in the ocean from satellite radiometer data. J Plankton Res 17:1245-1271

Longhurst AR (1998) Ecological geography of the sea. Academic Press, San Diego

Marañón E, Holligan PM (1999) Photosynthetic parameters of phytoplankton from $50^{\circ} \mathrm{N}$ to $50^{\circ} \mathrm{S}$ in the Atlantic Ocean. Mar Ecol Prog Ser 176:191-203

Marañón E, Holligan PM, Varela M, Mouriño B, Bale AJ (2000) Basin-scale variability of phytoplankton biomass, production and growth in the Atlantic Ocean. Deep-Sea Res Part I 47:825-857

Marañón E, Holligan PM, Barciela R, González N, Mouriño B, Pazó MJ, Varela M (2001) Pattern of phytoplankton sizestructure and productivity in contrasting open ocean environments. Mar Ecol Prog Ser 216:43-56

McArdle BH (1988) The structural relationship: regression in biology. Can J Zool 66:2329-2339

McGillicuddy DJ Jr, Robinson AR, Siegel DA, Jannasch HW, Johnson R, Dickey TD, McNeil J, Michaels AF, Knap AH (1998) Influence of mesoscale eddies on new production in the Sargasso Sea. Nature 394:263-266

Oschlies A, Garçon V (1998) Eddy-induced enhancement of primary production in a model of the North Atlantic Ocean. Nature 394:266-269

Pakulski JD, Benner R, Amon R, Eadie B, Whitledge T (1995) Community metabolism and nutrient cycling in the Mississippi River plume: evidence for itense nitrification at intermediate salinities. Mar Ecol Prog Ser 117:207-218

Shulenberger E, Reid JL (1981) The Pacific shallow oxygen maximum, deep chlorophyll maximum, and primary productivity, reconsidered. Deep-Sea Res Part I 28:901-919

Smith S, Mackenzie F (1987) The ocean as a heterotrophic system: implications for the global carbon cycle. Global Biogeochem Cycles 1:187-198

Steemann Nielsen E (1952) The use of radio-active carbon $\left({ }^{14} \mathrm{C}\right)$ for measuring organic production in the sea. J Cons Int Explor Mer 18:117-140

Tranvik LJ (1992) Allochthonous dissolved organic matter as an energy source for pelagic bacteria and the concept of the microbial loop. Hydrobiologia 229:107-114

Uz BM, Yoder JA, Osychny V (2001) Pumping of nutrients to ocean surface waters by the action of propagating planetary waves. Nature 409:597-600

White MA, Heywood KJ (1995) Seasonal and interannual changes in the North Atlantic subpolar gyre from Geosat and TOPEX/POSEIDON altimetry. J Geophys Res C 100: 24931-24941

Williams PJB (1993) On the definition of plankton production terms. ICES Mar Sci Symp 197:9-19

Williams PJB (1998) The balance of plankton respiration and photosynthesis in the open oceans. Nature 394:55-57

Williams PJB, Bowers DG (1999) Regional carbon imbalances in the oceans. Science 284:1735

Submitted: May 3, 2001; Accepted: October 18, 2001

Proofs received from author(s): April 15, 2002 